\title{
Differentiated Instruction In Multicultural Classroom Of Primary Years Programme In Gandhi Memorial Intercontinental School - Bali
}

\author{
P. I. Partami ${ }^{1}$, N. Padmadewi ${ }^{2}$, L. P. Artini ${ }^{3}$ \\ ${ }^{123}$ English Language Education, Post Graduate Program, The University of Pendidikan \\ Ganesha, Singaraja, Indonesia \\ e-mail: partami.putri@pasca.undiksha.ac.id, nyoman.padmadewi@pasca.undiksha.ac.id, \\ putu.artini@pasca.undiksha.ac.id
}

A multicultural classroom has significant student's diversity, especially in terms of language. The similar teaching strategy cannot be generated to cover all students' needs. Due to that problem, this study aimed at describing how differentiated instruction is planned, implemented, and assessed in multicultural classroom of Primary Years Programme in GMIS Bali, finding out challenges encountered by the PYP's homeroom teachers in practicing differentiated instruction in multicultural classroom, and analyzing teachers' perceptions toward differentiated instruction in multicultural classroom. The study employed mixed method. The data were collected through observation, interview, administering the questionnaire, and document study. The finding of this study are; first, teachers were practicing differentiated tasks through content, remedial task, product based on student's interest and reading buddy program through formative and summative assessment that was conducted in a unit. Second, the main challenge encountered by teachers of GMIS Bali was covering the standards to everyone meanwhile each student has different English proficiency and teachers have limited time for preparing DI. And third, teachers of GMIS Bali were showing positive perception toward DI by their awareness about the concept, implementation, and implication. Thus, this study has an important contribution to teacher's pedagogical and professional competence and there is a need for further research about how to anticipate the challenges that cannot be filled by the teachers.

Keywords: Differentiated Instruction, International School, Multicultural classroom, Primary Years Programme, Teacher's Opinion

\section{INTRODUCTION}

The latest data from ISC (2018) showed that there are now about 8,000 international schools around the world. It identified 1.003 English-medium international schools for children aged $3-18$ in South East Asia are teaching over 371.500 students. Six countries in the region now have over 100 international schools each; Indonesia, Thailand, Malaysia, Cambodia, Vietnam, and Singapore. No longer students' enrolment at international schools in South East Asia dominated by expertise. In addition, Indonesia placed as the $10^{\text {th }}$ global position of premium international schools by 192 schools. In Bali specifically, there are 11 international schools from primary to secondary level which are located in Denpasar, Badung, Buleleng, and Gianyar regencies. Generally, an international school has significant student's diversity in terms of nationalities, cultural background, and languages. In this case, multicultural classrooms happen in international school.

A multicultural classroom is an environment in which both its students and teacher are from different ethnic backgrounds accepting of all races, cultures, and religions (Hoosein, 2014). A multicultural classroom is not only students from different cultures, faiths, backgrounds, but also students with different learning, style, abilities, and intelligence (Allen, Paasche, Langford, and Nolan, 2002). In addition, Celik (2017) also states that there are many ways of today's learner vary such as experience, socioeconomic status, culture, ethnicity, learning styles, and in cognitive areas. Those diverse learners bring their own learning and 
personal character to the classroom that influence the classroom atmosphere, time management, content to be taught, and the ways the teacher teach. The diversity in multicultural classroom also brings some issues to teaching and learning activities, one of the big issues is language diversity.

Language diversity in a multicultural classroom has a strong influence on the content and process of schooling practices for both language-minority and language-majority of students. As a system of communication linking sound, written, or visual symbols, and meaning, language is an indispensable bridge for sharing knowledge, skills, values, and attitudes within and across cultures.

Students who are coming from non-native countries always get difficulties in order to understand the learning activities given and accomplish their work. And this is also affected by their English score. Most of them got under average - average marks. Basically, those nonnative English speaker students are smart students. They just do not understand towards the instructions given in the class. Besides that, some studies reported that because the education systems of students' cultures are different from the culture of their new classroom, the academic achievement of students may be low or bad (Alsubaie, 2015).

Thus, this language barrier issue is not only a big problem for non-native speakers' students, but also becomes a big challenge for the teacher in order to transfer the material to those students, because not all of the students master English as their daily language, but in fact, English is the main instructional language used in international school Bali. According to the phenomenon above, students in multicultural classroom have different English proficiency, thus, the similar teaching strategies cannot be generated in diverse class, moreover teacher must differentiate the content, process, product, and learning environment based on student's need.

Coming up from the introduction above, this paper described the differentiated instruction that practiced by homeroom teachers which focus on teachers' practices in planning, implementing, and assessing students in multicultural classroom. In addition, this research studied about the challenges encountered by the teacher and impact of differentiated instruction for students in multicultural classroom of primary years programme in international school Bali. Besides that, this study also analyzed the PYP teachers' perceptions towards differentiated instruction in terms of content, process, product, and learning environment in English subject.

\section{Differentiated Instruction}

Differentiated instruction is an educational philosophy. Differentiated instruction is an effective teaching method to deal with each student's needs in diverse classroom. By conducting this philosophy, the teacher can teach up all the students. Differentiation is a complex and perplexing concept. Tomlinson (1999) states differentiated instruction is not an instructional strategy or teaching model. It's a way of thinking about teaching and learning that advocates beginning where individuals are rather than with a prescribed plan of action, which ignore student readiness, interest, and learning profile. It is a way of thinking that challenge how teachers typically envision assessment, teaching, learning, classroom roles, use the time, and curriculum (Tomlinson, 2001). Differentiated instruction is observing and understanding the differences and similarities among students and use this information to plan a suitable instruction (Robb, 2008). In addition, she defined differentiated instruction is a way of teaching and it is not a program of worksheets. Differentiation is not a strategy but rather a way of teaching that accommodates differences among children so that all are learning on an ongoing basis (Roberts \& Inman, 2009: 2). They also defined differentiation is different with a purpose and the learning experiences should be at an appropriate level of difficulty for the learners. Westwood (2016) defines differentiated instruction is taking account of significant differences among students in terms of their ability, rate learning, language proficiency, literacy, and numeracy skills, and then using this knowledge to adapt the way the curriculum and learning activities are presented. 
There are four elements of differentiated instruction; content, process, product and learning environment (Tomlinson, 1999, 2001). These elements are highly interconnected and can be adjusted according to student's learner readiness, interest, and learning profile.

\section{a. Content}

Students need to learn content, information, and material in order to be successful in today's school. By differentiating student's content, the teacher prepares lesson plans that consider individual needs and abilities. Content is the input of teaching and learning (Tomlinson, 2001: 72). Content deals with what a student's needs to learn or how the student will gain access to the knowledge, ideas and skills. There are several strategies can be applied by teacher in order to differentiating content; concept-based teaching, curriculum compacting, learning contract, mini lessons, and varied support system. These strategies are useful in differentiating how a teacher ensures appropriate access to what a teacher needs students to learn.

\section{b. Process}

Process means opportunity for learners to process the content or ideas and skills to which they have been introduced (Tomlinson, 2001: 79). Process also can be defined as how the student will come to master and own the knowledge, ideas, and skills. In the language school, process is well known as a sense-making activity. Sense-making activity in differentiated instruction must be interesting to the students, call on the students to think at a high level, and cause the students to use a key skills to understand the key ideas (Tomlinson, 2001: 80). Tomlinson (2001: 81) also describes strategies that support differentiated processing such as; learning logs, journals, graphic organizers, creative problem solving, cubing, learning centers, interest centers, learning contracts, literature circles, role playing, cooperative controversy, choice boards, jigsaw, think-pair-share, and mind-mapping. Those strategies engage students in a different thinking or processing response, matches their learning needs, as well as special learning goals.

\section{c. Product}

The final outcomes of assessments are the product. A product is a long-term effort, because it reflects what the students learned (Tomlinson, 2001; 85). It is important for teachers to provide clear expectations and design the contents and processes to stretch the students even though scaffolding may be necessary to assure students experience success. An ideal product assignment should help students individually, or in groups to rethink, use, and extend what they have learned over a long period of time, it can be a unit, a semester, or even a year. Products are important for students' as an extensive understandings and applications, and to assess student knowledge, understanding, and skill (Tomlinson, 2001: 86).

\section{d. Learning Environment}

Differentiated instruction also emphasize on understanding student's background, social communicative abilities, and their learning conditions. Those are helping teacher in creating a stimulating learning environment, which have a significant impact on an individual's brain development and eventual level of intelligence. Tomlinson (2013) stated that learning environment refers to both the physical and the affective climate in the classroom. It is the weather that affects everything that happens there. That is why learning environment in one of important elements in differentiated instruction. There are several instructional strategies that support differentiated instruction in multicultural classroom; learning stations, agenda, learning centre, and student's portfolio.

According to Tomlinson (1999: 16) a differentiated classroom differs from a traditional classroom. There are comparisons between differentiated classroom and traditional classroom as mentioned on the following table.

Table 1. The comparison between traditional classroom and differentiated classroom (Tomlinson, 1999: 16)

\begin{tabular}{|l|l|}
\hline \multicolumn{1}{|c|}{ Traditional Classroom } & \multicolumn{1}{c|}{ Differentiated Classroom } \\
\hline $\begin{array}{l}\text { Student differences are masked or acted } \\
\text { upon when problematic. }\end{array}$ & $\begin{array}{l}\text { Student differences are studied as a basis } \\
\text { for planning. }\end{array}$ \\
\hline
\end{tabular}




\begin{tabular}{|l|l|}
\hline $\begin{array}{l}\text { Assessment is most common at the end of } \\
\text { the learning to see "who gets it". }\end{array}$ & $\begin{array}{l}\text { Assessment is ongoing and diagnostic to } \\
\text { understand how to make instruction more } \\
\text { responsive to learner need. }\end{array}$ \\
\hline $\begin{array}{l}\text { A relatively narrow sense of intelligence } \\
\text { prevails. }\end{array}$ & $\begin{array}{l}\text { Focus on multiple forms of intelligence is } \\
\text { evident. }\end{array}$ \\
\hline A single definition of excellence exists. & $\begin{array}{l}\text { Excellence is defined in large measure by } \\
\text { individual growth from a starting point. }\end{array}$ \\
\hline Students' interest is infrequently tapped. & $\begin{array}{l}\text { Students are frequently guided in making } \\
\text { interest-based learning choices. }\end{array}$ \\
\hline $\begin{array}{l}\text { Relatively few learning profile options are } \\
\text { taken into account. }\end{array}$ & $\begin{array}{l}\text { Many language profile options are available } \\
\text { for students. }\end{array}$ \\
\hline Whole class instruction dominates. & Many instructional arrangements are used. \\
\hline $\begin{array}{l}\text { Coverage of texts and curriculum guides } \\
\text { and drives instruction. }\end{array}$ & $\begin{array}{l}\text { Student readiness, interest, and learning } \\
\text { profile shape instruction. }\end{array}$ \\
\hline Single option assignments are the norm. & $\begin{array}{l}\text { Multi-option assignments are frequently } \\
\text { used. }\end{array}$ \\
\hline A single test prevails. & Multiple materials are provided. \\
\hline Time is relatively inflexible. & $\begin{array}{l}\text { Time is used flexibly in accordance with } \\
\text { students need. }\end{array}$ \\
\hline $\begin{array}{l}\text { Single interpretation of ideas and events } \\
\text { may be sought. }\end{array}$ & $\begin{array}{l}\text { Multiple perspectives on ideas and events } \\
\text { are routinely sought. }\end{array}$ \\
\hline The teacher directs students' behavior. & $\begin{array}{l}\text { The teacher facilitates students' skills at } \\
\text { becoming more self-reliant learners. }\end{array}$ \\
\hline The teacher solves problems, & $\begin{array}{l}\text { Students help other students and the } \\
\text { teacher solve problems. }\end{array}$ \\
\hline A single form of assessment is often used. & Students are assessed in multiple ways. \\
\hline $\begin{array}{l}\text { The teacher provides whole-class } \\
\text { standards for grading. }\end{array}$ & $\begin{array}{l}\text { Students work with the teacher to establish } \\
\text { both whole-class and individual learning } \\
\text { goals. }\end{array}$ \\
\hline
\end{tabular}

\section{Perception}

In psychology, philosophy and the cognitive sense, the definition of perception is the process of attaining awareness or understanding of sensory information. There are some definitions of perception come from expertise as following. Tubbs and Moss (2002) stated that perception is an active process as one selectively perceives, organizes and interprets what one experiences. They also stated that interpretations are based on the perceivers past experiences, assumptions about human behavior, knowledge of the others circumstances, present moods/wants/desires and expectations.

Perception refers to the way sensory information is organized, interpreted, and consciously experienced. Perceptions can also be affected by our beliefs, values, prejudices, expectations, and life experiences (Fawcett, Wang, \& Birch, 2005). Perception is the interpretation of stimuli as established by relating it to earlier perceptual sets which may be by way of experience, exposure or any other interaction (Hoosein, 2014). In addition, according to Vishal (2017), perception is the awareness of something through the senses. In other words it's the ability to see, hear, understand or become aware of something. Perception is important due to the following reasons:

a) It's a physiological process through which everything is this world is interpreted and understood.

b) It's the way people perceive things that defines their character and attitude. Kindness, hate, love and all other emotions originate from one's perceptions about something.

c) It is just perception which defines what happiness means to a person. For some earning money is happiness, for some spending money is happiness. 
d) Human perception towards god is the main reason why are having so many religions today. It not just shows that perceptions are varied but also perceptions of a few have the ability to influence the mankind as a whole.

e) Perceptions help in shaping up a person's goal and his/her outlook on life. It's the thing that initiates anyone to find their purpose in life.

Therefore, it can be concluded that perception is the interpretation of stimuli as established by relating it to earlier perceptual sets which may be by way of experience, exposure, or any other interaction. Relate to teacher's perception, teachers' perceptions have an enormous effect on the successful implementation of quality education in schools, quality of teaching and quality of learning. What teacher believes is also based on their experience, exposure, or any other interaction toward the things/issues.

This study investigated differentiated instruction in multicultural classroom of primary years programme in International schools Bali. In detail, the objectives of this study are describing differentiated instruction planned, implemented, and assessed in multicultural classroom of Primary Years Programme in Bali, finding out challenges encountered by the PYP's homeroom teachers in practicing differentiated instruction in multicultural classroom, and analyzing teachers' perceptions toward differentiated instruction in multicultural classroom.

\section{RESEARCH METHOD}

To achieve this goal, the researcher conducted a descriptive qualitative design as the data are in form of words and it involves obtaining holistic picture of what occurred in particular situations or settings. The source of data is English teaching and learning activities in multicultural classroom. The data was explained descriptively in form of words and analyzed inductively which means that conclusion was drawn at the end of the study after analyzing data obtained. Meanwhile, the purpose of this research also is to uncover teachers' perception towards differentiated instruction of multicultural classroom in Bali. The study is categorized as survey design with cross-sectional design to gather data in teachers' perspective toward the differentiated instruction. Therefore, the research method used in this study can be regarded as a Mixed Method Design.

In this research, 9 homeroom teacher as English subject teachers and 9 Para-educators of grade 1 to 5 were selected subjects for this study. 2 home room teachers are Indonesian, 7 homeroom teachers are Indian. Meanwhile all of Para-educators are Indonesian. Team teaching is implemented in International school. Thus, there is 1 homeroom teacher as the main teacher who is teaching the material in front of the class and 1 Para-Educator or well known as assistant teacher who is assisting students.

Research instrument has important role to investigate the result of the research, thus the researcher must prepare the instruments well. In this study, there are some instruments were used; observation checklist, interview guide, and questionnaire. In addition, the data sources of this study are students' portfolio, E-TAF, and unit planner.

The procedures in conducting mixed method of this study which are; (2012) which was simplified into 7 steps; 1) determining if a mixed methods study is feasible, 2) identifying a rationale for mixing method, 3) indentifying a data collection strategy, 4) developing quantitative, qualitative, and a mixed methods questions, 5) collecting quantitative and qualitative data, 6) analyzing data separately or currently, and 7) writing the report as one-or two- phase study.

In embedded design, both qualitative data and quantitative data were collected during a single study, the two data sets were analyzed separately, and they addressed different research questions. It means that it is possible if the qualitative and quantitative data are collected during the same time frame but independently.

In qualitative data analysis, this research used data analysis proposed by Miles and Huberman (1984, as cited in Sugiyono, 2010). There were four steps of activities that were systematically need to be conducted in this research, those are; data reduction, data display, and conclusion or drawing the report. Meanwhile, in quantitative data analysis, the data involves teacher's perception on differentiated instruction in terms of content, process, 
product, and learning environment as the questionnaire of teachers' perception. The instrument was developed by creating a blueprint. The questionnaire also was judged by two expertises in differentiated instruction of primary years programme. The purpose of expert judgment was to find out the validity of questionnaire. The questionnaire was examined by senior English lecturers and one expatriate of international school teacher in terms of the appropriateness of the items in the questionnaire with the research objectives. The expert judgment used rubric provided by the researcher to evaluate the instrument. The data from the expert judgment then was analyzed quantitatively using the formula of Gregory validity (adopted from Gregory 2000). the questionnaire developed in this study belong to the first category $(0.76 \leq X \leq 1.00)$ which means the teacher's perception towards differentiated instruction questionnaire for this study was considered as a questionnaire with very high validity.

In addition, for the test of item validity, the questionnaires were distributed to 18 respondents from Homeroom teachers and Para-Educators grade $1-5$ of international schools in Bali. Furthermore, the questionnaire items were tested by using Pearson product Moment. A test item was said to be valid if $r_{\text {observed }}$ is higher than $r_{\text {tabel. }}$. The test was conducted on significant level of $5 \%(0.05)$. The score of $r_{\text {tabel }}$ was 0.3338 .

Table 2. The result of reliability statistics

\begin{tabular}{|c|c|c|}
\hline Cronbach's Alpha & $\begin{array}{c}\text { Cronbach's Alpha Based on } \\
\text { Standardized Items }\end{array}$ & N of Items \\
\hline .849 & .852 & 35 \\
\hline
\end{tabular}

Reliability is the consistency of the test being used. The reliability of the questionnaire in this study was analyzed using SPSS 17.0 windows program. Table 1 shows the Cronbach's Alpha coefficient was .849 which means that all those items had high level of reliability.

\section{FINDINGS AND DISCUSSION}

The researcher found the process of practicing differentiated instruction in international schools Bali as illustrated on figure 1 bellow

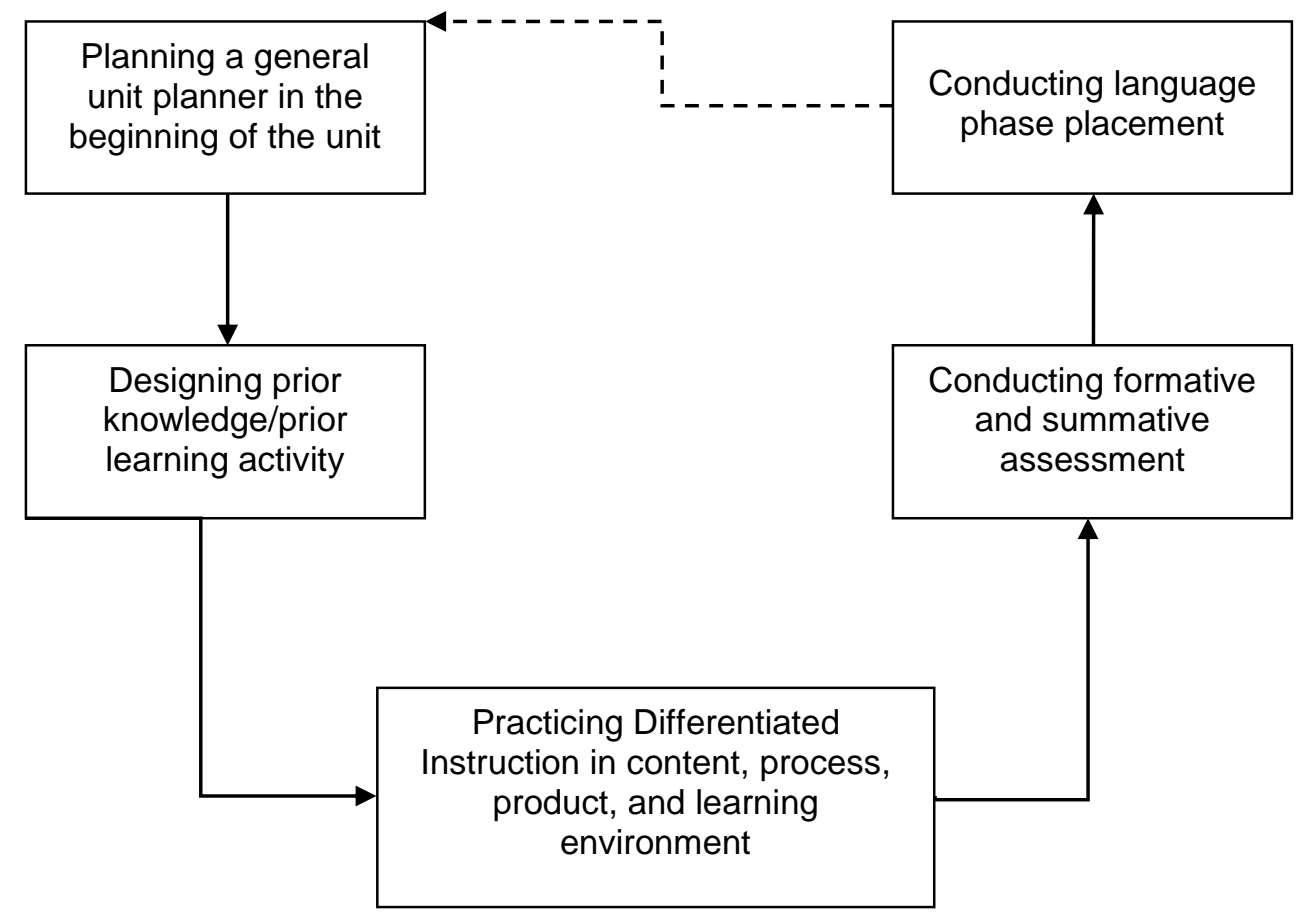

Figure 1. The process of practicing differentiated instruction in international schools Bali 
Figure 1 demonstrates the process of practicing differentiated instruction in international schools Bali. In the very beginning of the unit teachers planned a general unit planner according to several document such as; programme of inquiry, scope and sequence, syllabus, and making PYP happened book guidelines. The next step is teachers as well as English subject teachers designed a prior learning activity. The prior learning or well known as preassessment is conducted to analyze student's level of understanding towards the concept and also analyze English proficiency of every student. After that, teachers continued with planning differentiated planner that written on anecdotal record since there is no formal planner for differentiation. In practicing differentiated instruction, teachers always differentiate the four elements; those are content, process, product, and learning environment. It is also found that among teachers in international schools Bali conducted different strategies for differentiated instruction. For the brief explanation, it can be seen on the table 3 follows.

Table 3. The teaching strategies used by English teachers in differentiated instruction

\begin{tabular}{|l|l|}
\hline $\begin{array}{c}\text { 4 Elements of Differentiated } \\
\text { Instruction (Tomlinson, 1999 }\end{array}$ & \multicolumn{1}{|c|}{ Teaching strategies used by English teachers } \\
\hline Content & - Concept-based teaching emphasized on PYP key \\
& concepts \\
& - Using varied texts and resources materials \\
& - Differentiated tasks \\
& - Learning contract (Teacher-Student Conference) \\
& - Using varied support systems \\
& - Teacher's provocation questions \\
& - KWHL chart \\
& - Curriculum mapping \\
\hline Process & - Learning logs \\
& - Exhibition journal \\
& - Visualize graphic organizers \\
& - Creative problem solving \\
& - Mind-mapping \\
& - Reading buddy program \\
& - Remedial tasks \\
& - Student's portfolio \\
\hline Product & Making a product based on student's interest, examples: \\
& creating brochure, poster, newspaper, comic strips, \\
& essay, PowerPoint, and oral presentation. \\
\hline Learning Environment & - Mini library \\
& - Reading corner \\
& - Stations \\
& - Inquiry table \\
& - Reward chart \\
\hline & \\
\hline
\end{tabular}

In addition, the differentiated instruction classroom, teachers also conducted two forms of assessments; those are formative assessment and summative assessment. Generally, teachers conducted 3 formative assessments and 1 summative assessment for one unit. Teachers gave different tasks with different level of difficulties for students who have lack of English proficiency. Meanwhile the learning goal is same. Teachers and students also discussed the assessment rubric together. The assessment rubric was made as the guideline for students in doing their tasks. At the end of term, teachers will do English language phase placement for each student based on their performance during a term behind. This language phase is written in the form of learning outcomes that attached in progress report. Language phase placement will be used for the next term and/or next grade as the guideline and references for teachers to see their students' English proficiency. 
This study also found several differentiated instruction classroom criteria that practiced in International schools Bali. The comparison theory used is Differentiated Instruction by Tomlinson $(1999,2001)$. The detail can be seen on the following table

Table 4. The criteria of differentiated instruction classroom used in international school Bali

\begin{tabular}{|c|c|c|}
\hline $\begin{array}{l}\text { Differentiated Classroom } \\
\text { (Tomlinson, } 1999 \text { and 2001) }\end{array}$ & Available & $\begin{array}{c}\text { Not } \\
\text { Available }\end{array}$ \\
\hline 1. Student differences are studied as a basis for planning. & $\checkmark$ & \\
\hline $\begin{array}{l}\text { 2. Assessment is ongoing and diagnostic to understand how } \\
\text { to make instruction more responsive to learner need. }\end{array}$ & $\checkmark$ & \\
\hline 3. Focus on multiple forms of intelligence is evident. & $\checkmark$ & \\
\hline $\begin{array}{l}\text { 4. Excellence is defined in large measure by individual } \\
\text { growth from a starting point. }\end{array}$ & $\checkmark$ & \\
\hline $\begin{array}{l}\text { 5. Students are frequently guided in making interest-based } \\
\text { learning choices. }\end{array}$ & $\checkmark$ & \\
\hline 6. Many language profile options are available for students. & & $\checkmark$ \\
\hline 7. Many instructional arrangements are used. & $\sqrt{ }$ & \\
\hline $\begin{array}{l}\text { 8. Student readiness, interest, and learning profile shape } \\
\text { instruction. }\end{array}$ & & $\checkmark$ \\
\hline 9. Multi-option assignments are frequently used. & $\checkmark$ & \\
\hline 10. Multiple materials are provided. & $\checkmark$ & \\
\hline 11. Time is used flexibly in accordance with students need. & $\checkmark$ & \\
\hline $\begin{array}{l}\text { 12. Multiple perspectives on ideas and events are routinely } \\
\text { sought. }\end{array}$ & $\checkmark$ & \\
\hline $\begin{array}{l}\text { 13. The teacher facilitates students' skills at becoming more } \\
\text { self-reliant learners. }\end{array}$ & $\checkmark$ & \\
\hline $\begin{array}{l}\text { 14. Students help other students and the teacher solve } \\
\text { problems. }\end{array}$ & $\checkmark$ & \\
\hline 15. Students are assessed in multiple ways. & $\checkmark$ & \\
\hline $\begin{array}{l}\text { 16. Students work with the teacher to establish both whole- } \\
\text { class and individual learning goals. }\end{array}$ & $\checkmark$ & \\
\hline
\end{tabular}

Table 4 above represents some differentiated instruction criteria used in multicultural classroom of primary years programme in international schools Bali. The criteria are based on the comparison between classroom and differentiated classroom by Tomlinson $(1999,2001)$. There are 14 criteria out of 16 that observed and practiced by PYP teachers in international schools Bali. Two criteria which is not seen; many profile options are available for students. According to interview session with PYP curriculum coordinators, some the schools are still preparing and designing the criteria and document for language profile. Another criterion which is not seen; student readiness and learning profile shape instruction. Based on classroom observation and interview session with teachers, in practicing differentiated instruction, they are not specifically focus on differentiate the student's readiness and learning profile. It is only seen that teachers differentiated four elements based on student's interest by giving freedom to students in order to make product or giving any tasks based on student's interest. Thus, it is rarely seen that teachers emphasize on student's readiness and learning profile in international schools Bali.

According to semi-structured interviewed, this study found five challenges encountered by teachers of PYP level in Bali, those are; 1) Teachers feel differentiated instruction is challenging because they have to cover the standards for everyone, meanwhile each student has different English proficiency. 2) Teachers also fell that differentiate is challenging because they have absolutely no extra time for preparing and planning different tasks for students, meanwhile they have to teach many students in a class with different needs. 3) Teachers cannot differentiate instruction because they only have limited resource. 4) Teachers think differentiate instruction is demanding because her/his class is too small and have limited 
space for implementing it. Meanwhile, learning environment is one of vital element that support differentiated in classroom. 5) Another bigger challenges that encountered by teachers in implementing differentiated instruction is few students are totally having very basic English proficiency.

Meanwhile, the result of the questionnaire that had been shared to 18 Homeroom teachers and Para-Educators grade $1-5$ of international schools Bali can be seen on the following table.

Table 5. The result of the questionnaire in percentage for each statement

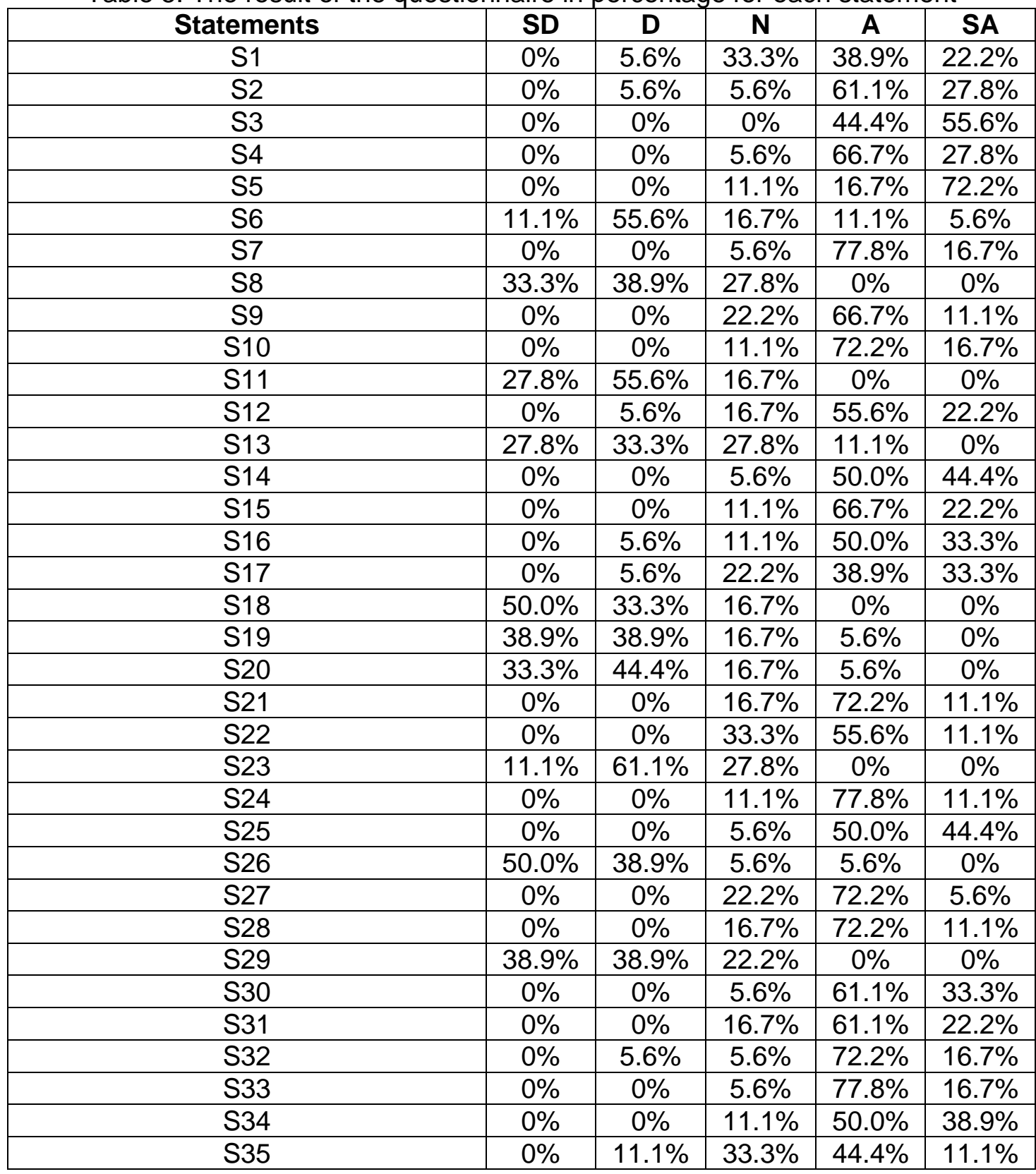

Note:

$\bar{S}$ : Statement

SD : Strongly disagree

D : Disagree

$\mathrm{N} \quad$ : Neutral

A : : Agree

SA : Strongly agree 
According to the result of questionnaire above, subjects of this study have positive opinions towards differentiated instruction. They collectively defined differentiated instruction similarly to expertise of the referred literature, it can be seen from teachers believed that differentiated instruction is interesting for students by conducting sense-making activity and by practicing differentiated instruction can help teachers to operate the classroom effectively.Based on the questionnaire also, it is shown that teachers are aware about the concept, implementation, and implication of differentiated instruction, although in answering open-ended question, they struggled explaining on how they plan the process in differentiated instruction based on student's readiness, interest, and learning profile.

\section{CONCLUSION AND SUGGESTIONS}

This study indentified several steps in practicing differentiated instruction in multicultural classroom in international school Bali, those are; 1) Planning a general unit planner according to several document such as; programme of inquiry, scope and sequence, syllabus, and making PYP happened book guidelines. 2) Designing a prior learning activity as a preassessment test. The prior learning or well known as pre-assessment is conducted to analyze student's level of understanding towards the concept and also analyze English proficiency of every student. 3) Planning differentiated planner that written on anecdotal record since there is no formal planner for differentiation. In practicing differentiated instruction, teachers always differentiate the four elements; those are content, process, product, and learning environment. It is also found that among teachers in international schools Bali conducted different strategies for differentiated instruction.4) Conducting formative and summative assessment. Generally, teachers conducted 3 formative assessments and 1 summative assessment for one unit. Teachers gave different tasks with different level of difficulties for students who have lack of English proficiency. Meanwhile the learning goal is same. Teachers and students also discussed the assessment rubric together. The assessment rubric was made as the guideline for students in doing their tasks. 5) English language phase placement for each student based on their performance during a term behind. This language phase placement will be used for the next term as the guideline for practicing differentiated instruction.

There are several strategies implemented by teachers in order to differentiate the content such as; concept-based teaching, using varied text and resources material, learning contract, and varied support system. Meanwhile in order to differentiate the process, teachers implemented weekly log journal, graphic organizer, and creating problem solving. Moreover, teachers gave free choices in making final product based on student's interest as one of implementation in differentiating instruction through product. And also several strategies in differentiating instruction through learning environment, teachers provided mini library, reading corner, stations, and inquiry table.

Finally, according to the result of questionnaire and open-ended questions, teachers have positive opinions towards differentiated instruction. They collectively defined differentiated instruction similarly to expertise of the referred literature, it can be seen from teachers believed that differentiated instruction is interesting for students by conducting sense-making activity and by practicing differentiated instruction can help teachers to operate the classroom effectively. Based on the questionnaire also, it is shown that teachers are aware about the concept, implementation, and implication of differentiated instruction, although in answering open-ended question, they struggled explaining on how they plan the process in differentiated instruction based on student's readiness, interest, and learning profile.

Thus, this study has an important contribution to teacher's pedagogical and professional competence and there is a need for further research about how to anticipate the challenges that cannot be filled by the teachers.

\section{REFERENCES}

Allen, K. E., Paasche, C.L., Langford, R., \& Nolan, K. (2002). Inclusion in Early Childhood Programs. Children with Exceptionalities, (3rd ed.). Canada: Nelson.

Alsubaie, M. A. (2015). Examples of current issues in the multicultural classroom. Departement of educational leadership, research, and technology. Western 
Michigan University. Journal of Education and Practice,6(10),86-90.

British Council. (2018). Understanding the primary school English curriculum. The United Kingdom's International Organisastion for cultural relations and educational opportunities.

Celik, S. (2017). Creating an inclusive and multicultural classroom by differentiated instruction. Inggris: Journal of English and Literature, 14(31), 478-493.

Creswell, J. W. (2012). Educational research: Planning, conducting, and evaluating quantitative and qualitative research $\left(4^{\text {th }} \mathrm{Ed}\right.$.). Thousand Oaks, CA: Sage.

Fawcett, S. L. \& Wang, Y. Z. \& Birch, E. (2005). The critical period for susceptibility of human stereopsis. Journal of American Association for Pediatric Ophthalmology and Strabismus, 9(10), 607-618.

Hoosein, S. (2014). Teacher' perspectives and multicultural diverse classrooms teachers' perspectives and instructional strategies in multicultural diverse classrooms. Retrieved from https://tspace.library.utoro

ISC. (2018, January). New data on international school suggest growth. Retrieved from https://www.relocatemagazine.com/articles/education-the-demand-forinternational-schools-in-asia-continues

Robb, L. (2008). Differentiating reading instruction: How to teach reading to meet the needs of each student. New York: Scholastic.

Roberts, J, L., \& Inman, T. (April, 2009). Preparing students leaders to make a difference: Adult guides are key. USA: Western Kentucky University.

Sugiyono. (2010). Metode penelitian kuantitatif kualitatif dan R\&D. CV Alfabeta: Bandung.

Tomlinson, C. A. (1999). The differentiated classroom:Responding to the needs of all learners. Alexandria, VA: Association for Supervision and Curriculum Development.

Tomlinson, C. A. (1999). The differentiated classroom.Alexandria, VA: Association for Supervision and Curriculum Development.

Tomlinson, C. A. (2001). Differentiate instruction in mixed-ability classrooms differentiate instruction (2 ${ }^{\text {nd }}$ Ed.). Alexandria, VA: Association for Supervision and Curriculum Development.

Tomlinson, C. A. (2003). Differentiation in practice: $A$ resources guide for differentiating curriculum, grade 5-9.Alexandria, VA: Association for Supervision and Curriculum Development.

Tomlinson, C. A., \& Imbeau, M. B. (2010). Leading and managing a differentiated classroom.ASCD. Alexandria: United Sates of America.

Tomlinson, C. A. (2013). Differentiating instruction using common core standards. [PowerPoint research presentation]. Presented at Best Practices Institute spring workshop conducted at the Institutes on Academic Diversity, Curry School of Education, University of Virginia, Charlottesville, VA.

Tomlinson, C. A., \& Moon, T. R. (2013). Assessment and student success in a differentiated classroom. ASCD. Alexandria: United States of America.

Tubbs, S. L., \& Moss, S. (2002). Human communication: Principles and context. United Kingdom: McGraw-Hill Education

Vishal, B. (2017). What is perception and why is it important. International Journal of Economic Research. 14(1), 757-770.

Westwood, P. (2016). What teachers need to know about differentiated instruction. Australia: ACER Press. 